\title{
MONITORING OF THE HARMFUL ORGANISM CLAVIBACTER MICHIGANENSIS SUBSP. MICHIGANENSIS IN ROMANIA, BETWEEN 2011-2018
}

\author{
Mariana-Simona Stancu ${ }^{1 *}$, Rodi Mitrea ${ }^{1}$ \\ ${ }^{1}$ University of Craiova, Faculty of Horticulture, A.I. Cuza street, no.13, Craiova, Dolj, Romania
}

\section{Current Trends in}

Natural Sciences

\begin{abstract}
Among the phytopathogenic bacteria in plants it is also Clavibacter michiganensis subsp. michiganensis, harmful organism present in most tomato growing regions. The establishment of the dissemination area is carried out by starting monitoring programs that extend over several years. In Romania, such a program has been carried out since 2011. In order to establish the contamination with this bacteria, there are not enough phytosanitary controls carried out during the vegetation period. It is compulsory to carry out laboratory tests to establish precisely the presence or absence of this harmful organism in tomato crops. Thus, the counties in which the tomato crops are contaminated with the bacteria of interest could be determined and it could be taken the phytosanitary measures of prevention and control.
\end{abstract}

Keywords: area, contamination, monitoring.

\section{INTRODUCTION}

Clavibacter michiganensis subsp. michiganensis $(\mathrm{Cmm})$ which produces "bacterial canker of tomato/vascular wilt of tomato" was a harmful quarantine organism until 2019, and was regulated at national level by "Government Decision no. 563/2007 for the approval of the methodological norms for applying the Government of the Ordinance no. 136/2000 regarding the protective measures against the introduction and spread of quarantine organisms for the supply of plants or plant products in Romania" and at European level by "Directive 2000/29/ EC on protection measures against the introduction into the community of plant or plant organisms and their liability in the community". Since the beginning of this year it is a non-quarantine regulated harmful organism, according to the "Commission implementing regulation (EU) 2019/2072 stablishing uniform conditions for the implementation of Regulation (EU) 2016/2031 of the European Parliament and the Council, as regards protective measures against pests of plants, and repealing Commission Regulation (EC) No 690/2008 and amending Commission Implementing Regulation (EU) 2018/2019".

Clavibacter michiganensis subsp. michiganensis attacks not only Solanum lycopersicum plants but also other solanaceae and non-solanaceae plants, being widespread throughout the world (figure 1). Every year appear new outbreaks of the disease which leading to substantial damage due to the decrease of the production of tomatoes and the deterioration of the quality and appearance of the fruits, thus becoming unfit for marketing (Rădulescu et al., 1970). 


\section{Current Trends in Natural Sciences}

Vol. 9, Issue 17, pp. 175-186, 2020

https://doi.org/10.47068/ctns.2020.v9i17.021

Current Trends in Natural Sciences (on-line)

ISSN: 2284-953X

Current Trends in Natural Sciences (CD-Rom)

ISSN: 2284-9521

ISSN-L: 2284-9521

ISSN-L: 2284-9521

Table 1. Distribution by continent and region of Clavibacter michiganensis subsp. michiganensis (modified by: https://gd.eppo.int/taxon/CORBMI/distribution)

\begin{tabular}{|c|c|c|}
\hline Continent & Country/Region & Distribution \\
\hline \multirow{5}{*}{ Africa } & South Africa & Present, widespread \\
\hline & Egipt, Kenya, Madagascar, Togo, Uganda, Zambia & Present, no details \\
\hline & Marocco, Tanzania, Tunisia, Zimbabwe & Present, restricted distribution \\
\hline & Democratic Republic of the Congo & Absent, unreliable record \\
\hline & Algeria & Absent, invalid record \\
\hline \multirow{5}{*}{ Asia } & Israel & Present, widespread \\
\hline & China, Iran, Japain, Lebanon & Present, no details \\
\hline & India, Indonesia, Republic Korea, Syria & Present, restricted distribution \\
\hline & Tawain, Thailand, Vietnam & Absent, unreliable record \\
\hline & Uzbekistan & Absent, pest eradicated \\
\hline \multirow{2}{*}{ North America } & Canada, USA & Present, widespread \\
\hline & Mexico & Present, restricted distribution \\
\hline \multirow[t]{2}{*}{ America Centrală } & $\begin{array}{l}\text { Belize, Costa Rica, Cuba, Dominica, Grenada, } \\
\text { Guadelupe, Panama, Dominican Republic }\end{array}$ & Present, no details \\
\hline & Martinique & Absent, unreliable record \\
\hline \multirow{3}{*}{ South America } & Uruguay & Present, widespread \\
\hline & Argentina, Brazil, Columbia, Peru & Present, no details \\
\hline & Chile, Ecuador & Present, restricted distribution \\
\hline \multirow{9}{*}{ Europe } & Greece, Russia, Switzerland, Turkey & Present, widespread \\
\hline & Armenia, Azerbaijan, Belarus & Present, no detail \\
\hline & Czech Republic, Italy, Poland, Portugal, Spain & Prezent, few occurences \\
\hline & $\begin{array}{l}\text { Bulgaria, Cyprus, France, Germany, Hungary, Latvia, } \\
\text { Romania, Serbia, Ukraine }\end{array}$ & Present, restricted distribution \\
\hline & Belgium, Jersey, United Kingdom & Absent, pest no longer present \\
\hline & Slovakia & Absent, intercepted only \\
\hline & Finland & Absent, no pest record \\
\hline & Austria, Ireland, Lithuania, Norway, Sweden & Absent, pest eradicated \\
\hline & Netherlands, Slovenia, Spain (Islas Canarias) & Transient, under eradication \\
\hline \multirow{3}{*}{ Oceania } & Australia & Present, widespread \\
\hline & Fiji, Guam, New Caledonia, Tonga & Present, no details \\
\hline & New Zealand & Present, restricted distribution \\
\hline
\end{tabular}




\section{Current Trends in Natural Sciences}

Vol. 9, Issue 17, pp. 175-186, 2020

https://doi.org/10.47068/ctns.2020.v9i17.021

Current Trends in Natural Sciences (on-line)

ISSN: 2284-953X

ISSN-L: 2284-9521
Current Trends in Natural Sciences (CD-Rom) ISSN: 2284-9521 ISSN-L: 2284-9521

According to EPPO Global databses, this bacteria is present on most continents, namely: Asia, Africa, America, Europe and Oceania. The detailed list by country distribution is shown in table 1. Clavibacter michiganensis subsp. michiganensis was first reported and isolated, in the early 20th century (1909-1910), by Smith, in the greenhouses of Grand Rapids, Michigan, USA, North America. (De León et al., 2011; Hausbeck et al., 2000).

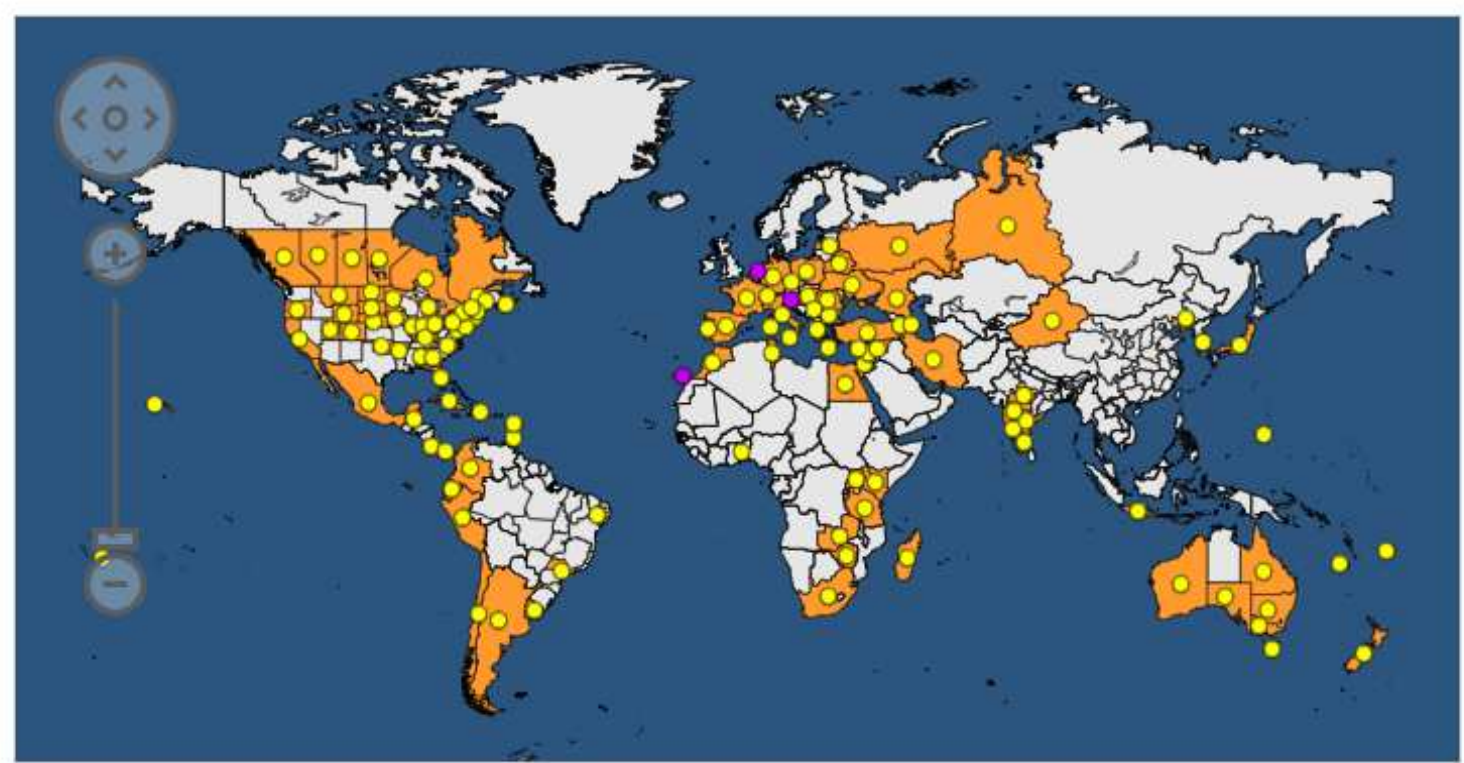

Figure 1. The geographical spread of Clavibacter michiganensis subsp. michiganensis (https://gd.eppo.int/taxon/CORBMI/distribution)

$\bigcirc$ present; $\bigcirc$ transient

In South America, it was first reported in 1958, in Brazil (Fatmi et al., 2017) and in 1983 in Chile. However, in the Azapa Valley area (from the Arica-Parinacota region - Chile), Clavibacter michiganensis subsp. michiganensis was not reported before 2012. It is assumed that the bacteria was introduced into this region with the infected seedlings (Chavera et al., 2013). Studies conducted in the greenhouses in the Valparaíso region showed that they were affected by $70.2 \%$ (Valenzuela et al., 2018).

In Oceania, the first report of this bacteria was in Australia, in 1925, then in New Zealand, in 1938 and in Africa, the first reporting was in 1942, in Moroc (Fatmi et al., 2017).

On the Asian continent, Clavibacter michiganensis subsp. michiganensis was first reported in Turkey, in 1950 (Fatmi et al., 2017). In 2001, this bacteria was introduced with tomato seeds or seedlings (Target cultivar) in Anatolia (Asian part of Turkey) (Şahin et al., 2002). In 2003, "Vascular wilt of tomato" also appears in greenhouses in the western Mediterranean region of Turkey, due to non-application of bactericides and relatively high humidity (Basim et al., 2004).

In 1963, this bacteria appeared in Israel, initially sporadically, then in 2000 a severe epidemic broke out, in the south of the country, in the most important tomato growing area. Finally it spreads both in the Gaza Strip and in the north of the country (Kleitman et al. 2007).

In Iran, the first reporting took place in 1988 (https://gd.eppo.int/taxon/CORBMI/distribution), and in Cyprus, in June 1998, in the Limassol district (in the Eptagonia mountain region) (Ioannou et al., 2000). 
Then, in 2002, Clavibacter michiganensis subsp. michiganensis was detected in two batches of tomato seeds on the island of Java in Indonesia (Anwar et al., 2004), and in 2007 it first appeared in Korea, in greenhouses where cherry tomatoes were grown (Myung et al., 2008). Also, in the same year, in 2007, in Syria, the first detailed evidence of this disease appeared. In the greenhouses contaminated with Clavibacter michiganensis subsp. michiganensis, from this country, the incidence of the disease was $15 \%$ in spring of 2007, rising to $70 \%$ at the end of July (Ftayeh et al. 2008).

In the center and northwest of the Russian Federation, between 2011-2017, severe outbreaks of the disease appeared, not only in tomato culture but also in potato culture. Laboratory tests revealed that the infection was caused by the bacteria mentioned above, being isolated from both plants and potato tubers (Ignatov et al., 2018).

In northern India (Himachal Pradesh state) this pathogen was detected not only on species of Lycopersicon and Capsicum, but also on species of Solanum douglasi, S. nigrum, S. mammosum and Nicotiana glutinosa (Singh and Bharat, 2017).

In Europe, Italy, in 1914, was the first country to report the presence of Clavibacter michiganensis subsp. michiganensis (https://efsa.onlinelibrary.wiley.com/doi/epdf/10.2903/j.efsa.2014.3721). In July 2010, in the province of Viterbo, from the central of Italy, severe outbreaks of the disease occurred in sixteen fields. It has been established that the incidence of the disease was between 70 and $100 \%$ and that the hybrid Uno Rosso was the most sensitive of the studied varieties. (Lamichhane et al., 2011).

Also, there were first reports of Clavibacter michiganensis subsp. michiganensis also in Denmark (1922), Lithuania (1930), and Hungary (1959) (Fatmi et al., 2017; https://gd.eppo.int/taxon/CORBMI/distribution).

Sutic first described this bacteria in Serbia, in 1957. For more than 50 years, it did not represent a serious threat to tomato production. Between 2006-2007, there was extensive surveillance of Clavibacter michiganensis subsp. michiganensis, in greenhouse and field tomato crops, from Leskovac, Lebane, Padinska Skela, Sabac, Trstenic, Ub, Stara Pazova and Cacak. It has been found that in the field, the incidence of the disease can reach up to $100 \%$, and in tomato greenhouses, it varies between 2 and 50\% (Milijaŝević et al., 2009).

Regarding the first report of this bacteria in Romania, it was done by Elena Bucur, in 1955, in Ilfov county (Marinescu et al., 1986; Rădulescu et al., 1970). In 1970, there was a devastating attack, with losses of over $90 \%$, in the greenhouses of our country. Bacteriologists from the Institute of Plant Protection from Bucharest have established a set of measures for the protection of tomato plants, which have led to decreasing losses in the following years. Also, they in collaboration with the researchers from the Research Station Işalniţa initiated a system of thermal disinfection of tomato seeds (Severin and Iliescu, 2006).

\section{MATERIALS AND METHODS}

In 2011, in Romania, the first monitoring program was started which was named "Monitoring plan for quarantine organisms Clavibacter michiganensis subsp. michiganensis and Xanthomonas campestris pv. vesicatoria". Then, in 2016, this plan was extended to other harmful organisms in tomato and pepper crops, becoming "Program for monitoring quarantine viruses in tomatoes and quarantine bacteria in tomatoes and peppers" (https://www.madr.ro/docs/fitosanitar/programemonitorizare/pm-virusi-carantina-tomate-ardei-update-22.11.2016.pdf).

The main objectives of this monitoring program are: 
- verification of the conformity of the plants intended for planting with the specific requirements, in order to issue the phytosanitary passport;

- updating the spread of the target organisms;

- the eradication of the harmful organisms detected or the prevention of their spread, when eradication is not possible;

- checking the health status of seeds and plants intended for planting, which come from intraCommunity circulation or from import.

Under this program, the phytosanitary inspectors, from the County Phytosanitary Offices, have the obligation to inspect, not only the commercial crops and the seed crops of tomatoes and peppers, during the vegetation period, but also the planting material and the seeds, from the internal production. The planting material and seeds, coming from the intra-Community circulation and from the import, are controlled either by the phytosanitary inspectors from the Border Inspections Points or either by the inspectors from the County Phytosanitary Offices. Both services belong to the Phytosanitary Direction of the National Phytosanitary Authority.

According to this monitoring program, the inspection is performed on both diagonals of the culture. Depending on the surface of the culture, a number of control points are established, as follows: areas up to 15 hectares are controlled in 5 points, and the areas over 15 hectares are controlled in 10 points. The number of plants examined at each control point is 200. As for the control in greenhouses, this is done according to the size of the greenhouse, the percentage of plants examined being $1-4 \%$.

If during the inspections carried out during the vegetation period, plants with characteristic symptoms of the disease are observed, they are collected and sent for laboratory analysis. Each County Phytosanitary Office determines the number of samples it will collect send for analysis. This thing depends on: the number of registered producers, the phytosanitary status of the host plants and the symptoms observed during the inspection.

If the inspection takes place at the seed material, sampling is required (10000 seeds or 10 seedlings) according to the monitoring program.

All inspections will be recorded in a form ("Inspection sheet", "Phytosanitary passport inspection sheet" or "Import phytosanitary inspection sheet"), as the case may be (https://www.madr.ro/docs/ fitosanitar/programe-monitorizare/pm-virusi-carantina-tomate-ardei-update-22.11.2016.pdf).

All the samples collected by the phytosanitary inspectors are packaged appropriately, to avoid contamination between the samples and sent, as soon as possible, to avoid deterioration, to the National Phytosanitary Laboratory of the National Phytosanitary Authority. The samples sent to the laboratory are necessarily coded and accompanied by a request for analysis. Once arrived at the destination, the samples are taken by an operator from the "Reception of samples" and they receive a laboratory code. According to the requested pest organism, the samples are taken from the bacteriology and/or virology laboratory. If the samples are not analysed as soon as they arrive, they are kept at room temperature (in the case of seeds) or in the refrigerator (in the case of plant material). After performing the bacteriological and/or virological analyses and determining whether the analysed sample is infected with one or more harmful organisms concerned, a "Laboratory report" is issued, which is sent to the County Phytosanitary Offices/Border Inspections Points, from where the sample was sent. After receiving the results of analyses, the phytosanitary inspectors have the obligation to inform the beneficiary of the test about the result of the analysis.

At the end of the year, the phytosanitary inspectors have the obligation to complete " The evaluation sheet of the situation regarding the quarantine viruses in tomatoes and the quarantine bacteria in 
tomatoes and peppers" and send it to the national rapporteur (the person designated by the National Phytosanitary Authority with centralization data). The national rapporteur draws up a report which it sends to the National Phytosanitary Authority.

During this monitoring we analyzed the samples received from phytosanitary inspectors, establishing whether the samples received are contaminated or not with Clavibacter michiganensis subsp. michiganensis and also, at the end of each monitoring year, we centralized the data received from the inspectors, drafting a report about bacteria and viruses monitoring at tomatoes and peppers.

\section{RESULTS AND DISCUSSIONS}

If following the laboratory analyses, at the plants covered by this monitoring program, at least one sample is contaminated with one or more monitored organisms, the parcel or lot is declared contaminated and are subject to plant protection measures.

In such situations, the phytosanitary inspectors have the obligation to write "Notification of measures" and to send it to the beneficiary. They estabilish the phytosanitary measures that the producer is obliged to apply in order to eradicate and prevent the spread of the harmful organism detected. Phytosanitary inspectors also draw up an " Information regarding the investigation carried out in order to establish the path of introduction of the harmful organism". The two above mentioned documents are transmitted, within a maximum three working days, to the Phytosanitary Direction of the National Phytosanitary Authority (https://www.madr.ro/docs/fitosanitar/programemonitorizare/pm-virusi-carantina-tomate-ardei-update-22.11.2016.pdf).

According to the "Guide for the recognition and control of diseases and pests in tomatoes grown in protected areas (greenhouses, indoor protected area and tunnels)", drafted by the National Phytosanitary Authority, the phytosanitary measures to be applied in the situation of detection of Clavibacter michiganensis subsp. michiganensis are: preventive measures (use of certified planting material; performing thermal and chemical treatments on the seed material; appropriate seed extraction; use of resistant varieties; crop rotation; drip irrigation; weed control; removal of attacked plants and surrounding plants; destruction by burning of vegetal debris; treatment of soil with copper products; application of appropriate decontamination measures) and curative measures (chemical control with: Curenox 50, Bordeaux juice, "MIF", Super Cupertine and Alcupral 50 PU) (http://www.anfdf.ro/sanatate/ghid/ghid_tomate_2019.pdf).

Regarding the situation of the harmful organism Clavibacter michiganensis subsp. michiganensis, in Romania, following the centralization of the data received from the phytosanitary inspectors, between the years 2011-2018, has been established:

- the annual number of samples of Solanum lycopersicum collected and analyzed for the detection of Clavibacter michiganensis subsp. michiganensis (table 2);

- the annual number of the samples contaminated with Clavibacter michiganensis subsp. michiganensis (table 3);

- the area of Solanum lycopersicum monitored/inspected/contaminated with this bacteria (table 4);

- the surface of Solanum lycopersicum contaminated with Clavibacter michiganensis subsp. michiganensis, by county (table 5);

After centralizing the data, we were able to draw up maps with the counties in Romania where the target bacterium was detected (figure 2). 


\section{Current Trends in Natural Sciences}

Vol. 9, Issue 17, pp. 175-186, 2020

https://doi.org/10.47068/ctns.2020.v9i17.021

Current Trends in Natural Sciences (on-line)

ISSN: 2284-953X

Current Trends in Natural Sciences (CD-Rom)

ISSN: 2284-9521

ISSN-L: 2284-9521

ISSN-L: $2284-9521$

During this period, in addition to the samples of the plants/part of plants of Solanum lycopersicum, contaminated with Clavibacter michiganensis subsp. michiganensis, additionally were found contaminated 3 samples of tomato seedlings: 1 sample from Bacău (domestic production, 2015) and 2 samples from Hunedoara (intra-Community circulation/import, 2016). Aso, there were found infected with Clavibacter michiganensis subsp. michiganensis, 11 samples (2 Buzau, 2 Iasi, 7 Ilfov) of tomato plants from the beneficiaries, in 2011 and 2 samples (1 Gorj, 1 Suceava) from the the territory surveillance, in 2014.

Table 2. The annual number of samples of Solanum lycopersicum analyzed for the detection of Cmm

\begin{tabular}{|c|c|c|c|c|c|}
\hline \multirow{2}{*}{$\begin{array}{c}\text { Year of } \\
\text { monitoring }\end{array}$} & \multicolumn{2}{|c|}{$\begin{array}{c}\text { Samples from internal } \\
\text { production }\end{array}$} & \multirow{2}{*}{$\begin{array}{c}\text { Samples from County } \\
\text { Phytosanitary Offices } \\
\text { (intra-Community circulation) }\end{array}$} & \multirow{2}{*}{$\begin{array}{l}\text { Samples from Border } \\
\text { Inspections Points } \\
\text { (intra-Community } \\
\text { circulation/import) }\end{array}$} & \multirow{2}{*}{\begin{tabular}{|c|} 
The total \\
number of \\
the samples
\end{tabular}} \\
\hline & $\begin{array}{c}\text { Plants/part of } \\
\text { plants }\end{array}$ & Seeds & & & \\
\hline 2011 & 107 & 32 & 28 & 86 & 253 \\
\hline 2012 & 80 & 24 & 42 & 59 & 205 \\
\hline 2013 & 82 & 26 & 71 & 59 & 238 \\
\hline 2014 & 61 & 11 & 58 & 37 & 167 \\
\hline 2015 & 66 & 21 & 45 & 31 & 163 \\
\hline 2016 & 66 & 27 & 55 & 39 & 187 \\
\hline 2017 & 87 & 21 & 31 & 25 & 164 \\
\hline 2018 & "117 & 26 & 37 & 46 & 226 \\
\hline
\end{tabular}

Table 3. The annual number of the samples contaminated with Cmm

\begin{tabular}{|c|c|c|}
\hline $\begin{array}{l}\text { Year of } \\
\text { monitoring }\end{array}$ & \begin{tabular}{|c|}
$\begin{array}{c}\text { The total number of the samples } \\
\text { of plants/part of plants } \\
\text { contaminated with } \mathrm{Cmm}\end{array}$ \\
\end{tabular} & $\begin{array}{l}\text { The total number of the samples of plants/part of plants } \\
\text { contaminated with } \mathrm{Cmm} \text { / county }\end{array}$ \\
\hline 2011 & 42 & $\begin{array}{l}\text { Alba, } 1 \text { Arad, } 7 \text { Argeş, 1 Constanța, } 13 \text { Dolj, } 5 \text { Galați, } 2 \\
\text { Harghita, } 1 \text { Hunedoara, } 2 \text { Olt, } 2 \text { Prahova, } 5 \text { Sălaj, } 2 \text { Vâlcea }\end{array}$ \\
\hline 2012 & 21 & $\begin{array}{l}1 \text { Alba, } 1 \text { Arad, } 3 \text { Argeş, } 7 \text { Dolj, } 1 \text { Iaşi, } 2 \text { Olt, } 5 \text { Prahova, } 1 \\
\text { Suceava }\end{array}$ \\
\hline 2013 & 6 & 1 Cluj, 3 Olt, 2 Prahova \\
\hline 2014 & 11 & 3 Argeş, 1 Harghita, 3 Olt, 1 Prahova, 2 Suceava, 1 Sălaj \\
\hline 2015 & (25 & 1 Gorj, 1 Harghita, 1 Ilfov, 2 Suceava \\
\hline 2016 & 7 & 1 Ilfov, 2 Prahova, 4 Dolj \\
\hline 2017 & 6 & 1 Galați, 1 Hunedoara, 1 Iaşi, 1 Olt, 1 Mehedinți, 1 Vâlcea \\
\hline 2018 & 8 & 1 Bacău, 3 Argeş, 1 Harghita, 2 Olt, 1 Vrancea \\
\hline
\end{tabular}

After analyzing the aforementioned data, regarding the number of samples from the units served to take samples, it was found that the largest number of samples of Solanum lycopersicum comes from domestic production, compared to the number of samples from import and intra-Community circulation (figure 3). Also, although the number of samples varied from year to year, the number of cases contaminated with Clavibacter michiganensis subsp. michiganensis was initially large, then decreased to eventually remain relatively constant (figure 4). 


\section{Current Trends in Natural Sciences}

Vol. 9, Issue 17, pp. 175-186, 2020

https://doi.org/10.47068/ctns.2020.v9i17.021

Current Trends in Natural Sciences (on-line)

ISSN: 2284-953X

Current Trends in Natural Sciences (CD-Rom)

ISSN: 2284-9521

ISSN-L: 2284-9521

ISSN-L: 2284-9521
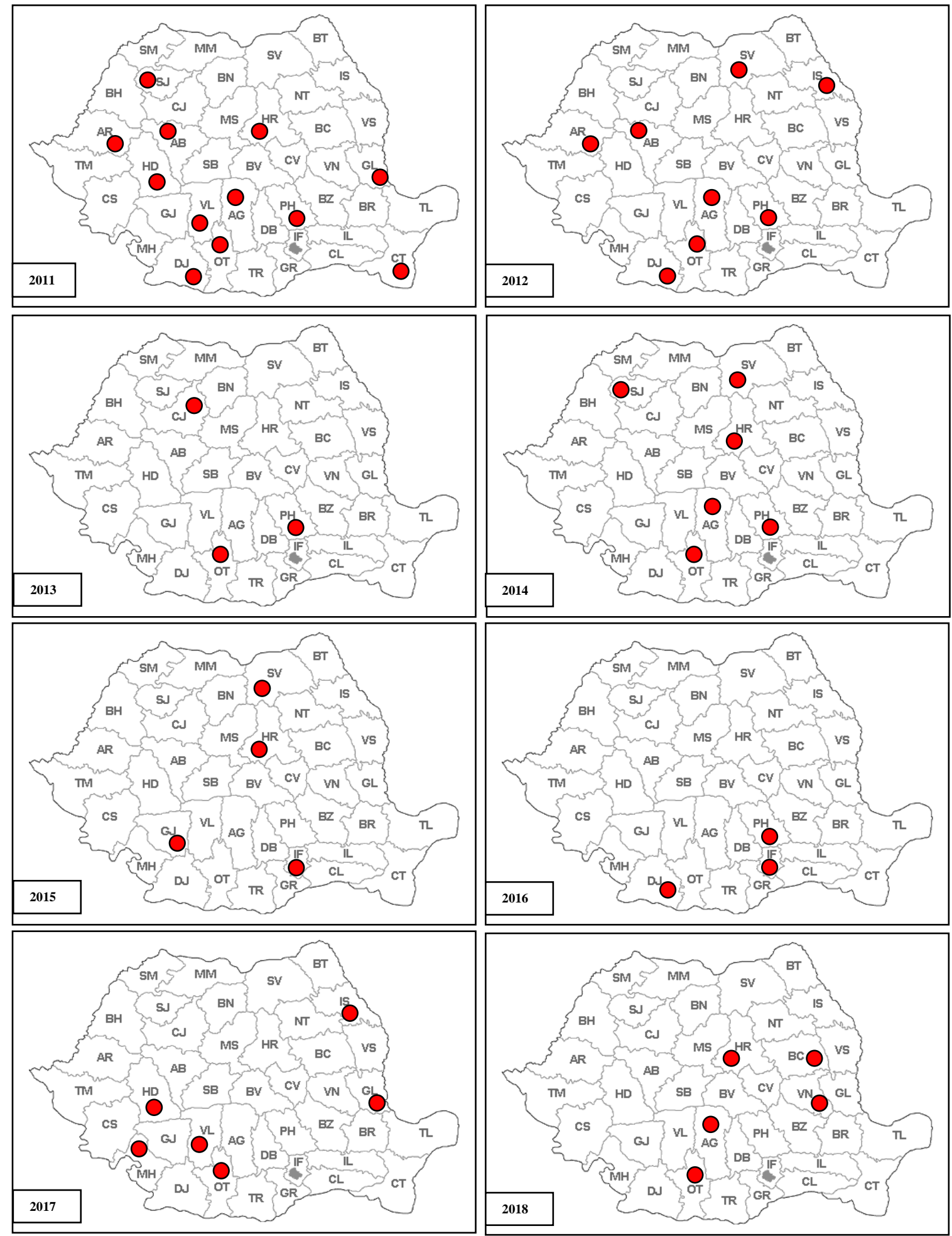

Figure 2 Counties contaminated with Cmm (2011-2018)

Ocontaminated 


\section{Current Trends in Natural Sciences}

Vol. 9, Issue 17, pp. 175-186, 2020

https://doi.org/10.47068/ctns.2020.v9i17.021

Current Trends in Natural Sciences (on-line)

ISSN: 2284-953X

Current Trends in Natural Sciences (CD-Rom)

ISSN: 2284-9521

ISSN-L: 2284-9521

ISSN-L: 2284-9521

Table 4. The area of Solanum lycopersicum monitored/inspected/contaminated with Cmm

\begin{tabular}{||c||r||r||r|}
\hline \hline $\begin{array}{c}\text { Year of } \\
\text { monitoring }\end{array}$ & $\begin{array}{c}\text { The surface of tomatoes } \\
\text { monitored }\end{array}$ & $\begin{array}{c}\text { The inspected surface / the } \\
\text { percentage of the inspected } \\
\text { surface of the total surface }\end{array}$ & $\begin{array}{c}\text { Surface contaminated with } \\
\text { Cmm / percentage of } \\
\text { contaminated surface of the } \\
\text { inspected surface }\end{array}$ \\
\hline \hline $\mathbf{2 0 1 1}$ & $37034.230 \mathrm{ha}$ & $3230.511 \mathrm{ha} / 8.72 \%$ & $13.050 \mathrm{ha} / 0.40 \%$ \\
\hline \hline $\mathbf{2 0 1 2}$ & $36344.630 \mathrm{ha}$ & $2340.380 \mathrm{ha} / 6.43 \%$ & $4.150 \mathrm{ha} / 0.17 \%$ \\
\hline \hline $\mathbf{2 0 1 3}$ & $36254.420 \mathrm{ha}$ & $2211.460 \mathrm{ha} / 6.09 \%$ & $0.080 \mathrm{ha} / 0.0036 \%$ \\
\hline \hline $\mathbf{2 0 1 4}$ & $35196.131 \mathrm{ha}$ & $1847.874 \mathrm{ha} / 5.25 \%$ & $0.808 \mathrm{ha} / 0.04 \%$ \\
\hline \hline $\mathbf{2 0 1 5}$ & $34629.245 \mathrm{ha}$ & $2042.455 \mathrm{ha} / 5.89 \%$ & $0.440 \mathrm{ha} / 0.02 \%$ \\
\hline \hline $\mathbf{2 0 1 6}$ & $36374.650 \mathrm{ha}$ & $1799.780 \mathrm{ha} / 4.94 \%$ & $0.860 \mathrm{ha} / 0.04 \%$ \\
\hline \hline $\mathbf{2 0 1 7}$ & $38178.546 \mathrm{ha}$ & $1354.593 \mathrm{ha} / 3.54 \%$ & $0.880 \mathrm{ha} / 0.06 \%$ \\
\hline \hline $\mathbf{2 0 1 8}$ & $39208.555 \mathrm{ha}$ & $1396.730 \mathrm{ha} / 3.56 \%$ & $1.1 \mathrm{ha} / 0.07 \%$ \\
\hline \hline
\end{tabular}

Table 5. Surface of Solanum lycopersicum contaminated with Cmm by county

\begin{tabular}{|c|c|}
\hline $\begin{array}{c}\text { Year of } \\
\text { monitoring }\end{array}$ & Surface contaminated with $\mathrm{Cmm} /$ county \\
\hline 2011 & $\begin{array}{l}\text { Alba - } 0.04 \text { ha, Arad - } 0.12 \text { ha, Argeş - } 7 \text { ha, Constanța - } 2 \text { ha, Dolj - } 0.95 \text { ha, Galați - } 0.15 \text { ha, } \\
\text { Harghita - } 0.06 \text { ha, Hunedoara - } 0.00075 \text { ha, Olt - } 0.05 \text { ha, Prahova - } 0.04 \text { ha, Sălaj - } 0.64 \text { ha, } \\
\text { Vâlcea - } 2 \text { ha }\end{array}$ \\
\hline 2012 & $\begin{array}{l}\text { Alba - } 0.4 \text { ha, Arad - } 0.5 \text { ha, Argeş - } 0.42 \text { ha, Dolj - } 1.82 \text { ha, Iaşi - } 0.01 \text { ha, Olt - } 0.03 \text { ha, } \\
\text { Prahova - } 0.92 \text { ha, Suceava - } 0.05 \text { ha }\end{array}$ \\
\hline 2013 & Cluj - 0.02 ha, Olt - 0.01 ha, Prahova - 0.05 ha \\
\hline 2014 & $\begin{array}{l}\text { Argeş - } 0.6 \text { ha, Harghita - } 0.02 \text { ha, Olt - } 0.01 \text { ha, Prahova - } 0.035 \text { ha, Sălaj - } 0.11 \text { ha, } \\
\text { Suceava - } 0.033 \text { ha }\end{array}$ \\
\hline 2015 & Gorj - 0.2 ha, Harghita - 0.02 ha, Ilfov - 0.2 ha, Suceava - 0.02 ha \\
\hline 2016 & Dolj - 0.63 ha, Ilfov - 0.13 ha, Prahova - 0.1 ha \\
\hline 2017 & Galați - 0.01 ha, Hunedoara - 0.08 ha, Iaşi - 0.46 ha, Olt - 0.03 ha, Mehedinți - 0.1 ha, Vâlcea - 0.2 ha \\
\hline 2018 & Argeş - 0.5 ha, Bacău - 0.14 ha, Harghita - 0.05 ha, Olt - 0.2 ha, Vrancea - 0.21 ha \\
\hline
\end{tabular}

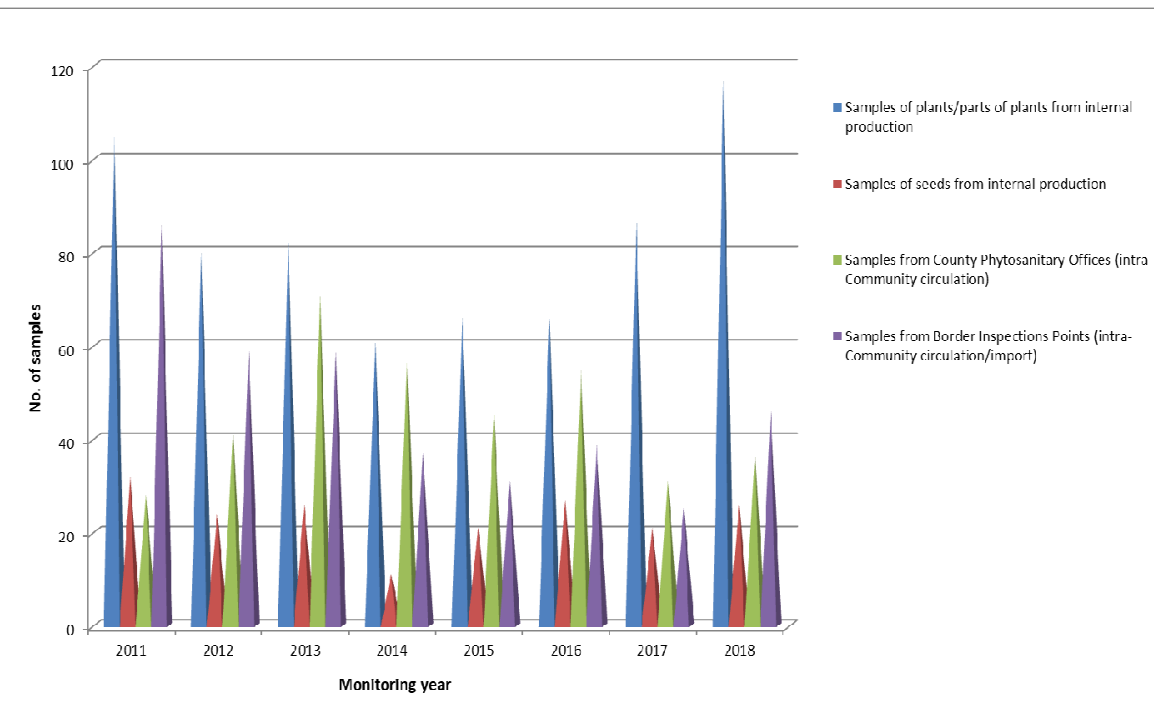

Figure 3. Evolution of the number of samples of Solanum lycopersicum, between 2011-2018 


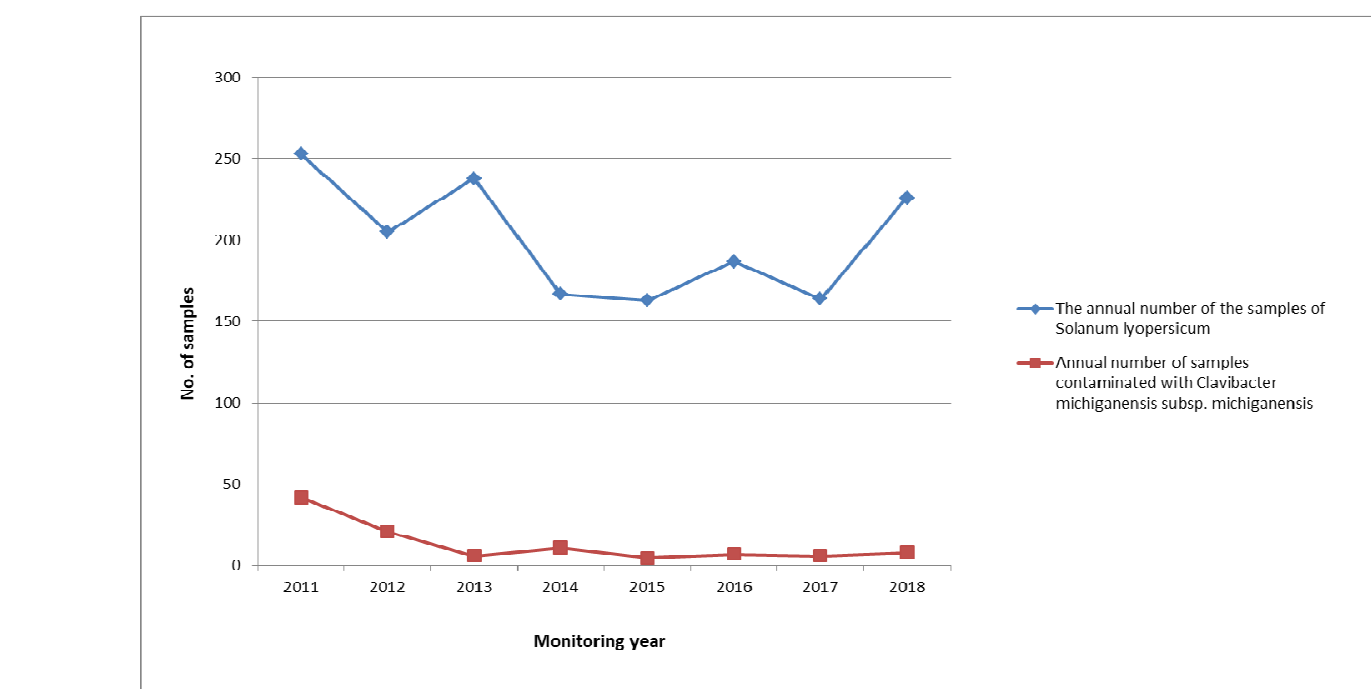

Figure 4. Comparative graph of the evolution of the total number of samples of tomatoes, with the number of samples contaminated with Cmm, between 2011-2018

\section{CONCLUSIONS}

Between 2011-2018, the number of the samples sent for analysis, by the County Phytosanitary Offices from the territory of Romania and analyzed by the National Phytosanitary Laboratory has varied, being the highest in the first year of monitoring. In the following years, although the surface area of tomato cultivation increased, the surface area inspected decreased, which implicitly led to a decrease in the number of samples collected and analyzed. This thing led to decrease the number of samples contaminated with Clavibacter michiganensis subsp. michiganensis and implicitly at reducing the surface of tomatoes contaminated with this harmful organism.

The number of positive cases was not constant in the counties either. The number of samples contaminated with this bacteria decreased or was equal to zero in the counties where the control and prevention measures recommended by the phytosanitary legislation were properly applied. In counties where these measures were not properly applied, the number of contaminated samples remained constant or even increased. Therefore, phytosanitary measures have a very important role in increasing or decreasing the number of positive cases.

Given the relatively small number of samples and implicitly the small number of positive samples, it is very likely that, if the number of samples collected and analyzed would increase, the number of samples contaminated with Clavibacter michiganensis subsp. michiganensis would also increase.

\section{REFERENCES}

Anwar, A., Van der Zouwen, P.S., Ilyas, S., Van der Wolf, J.M. (2004). Bacterial canker (Clavibacter michiganensis subsp. michiganensis) of tomato in commercial seed produced in Indonesia. Plant Disease, 88(6), 680-680.

Basim, E., Basim, H., Dickstein, E.R., Jones, J.B. (2004). Bacterial canker caused by Clavibacter michiganensis subsp. michiganensis on greenhouse-grown tomato in the western Mediterranean Region of Turkey. Plant Disease, 88(9), 1048.

Chavera, G.F.S., Martínez, R.S., Briones, C.S., Vásquez, R.G. (2013). First report of tomato bacterial canker Clavibacter michiganensis subsp. michiganensis on tomato crops in Arica. IDESIA (Chile) Mayo-Agosto, 31(2), 99-101.

De León, L., Siverio, F., López, M. María, Rodríguez Ana (2011). Clavibacter michiganensis subsp. michiganensis seedborne tomato pathogen: healthy seeds are still the goal. Plant Diseases, 95(11), 1328-1338. 


\section{Current Trends in Natural Sciences}

Vol. 9, Issue 17, pp. 175-186, 2020

https://doi.org/10.47068/ctns.2020.v9i17.021

Current Trends in Natural Sciences (on-line)

ISSN: 2284-953X

Current Trends in Natural Sciences (CD-Rom)

ISSN: 2284-9521

ISSN-L: 2284-9521

ISSN-L: 2284-9521

Fatmi, M.B., Walcott, R.R., Schaad N.W. (2017). Detection of Clavibacter michiganensis subsp. michiganensis in tomato seeds. Detection of plant-pathogenic bacteria in seeds and other planting material (Second edition, Chapter 17, pp. 111-117). APS PRESS, Minnesota.

Ftayeh, R.M., Von Tiedemann, A., Koopmann, B., Rudolph, K. (2008). First record of Clavibacter michiganensis subsp. michiganenesis causing canker of tomato plants in Syria. Plant Disease, 92(4), 649 - Abstract.

Hausbeck, M.K., Bell, J., Medina-Mora, C., Podolsky, R., Fulbright, D.W. (2000). Effect of bactericides on population sizes and spread of Clavibacter michiganensis subsp. michiganensis on tomatoes in the greenhouse and on disease development and crop yield in the field. Phytopathology, 90(1),38-44.

Ignatov, A.N., Spechenkova, N.A., Taliansky, M., Kornev, K.P. (2018). First report of Clavibacter michiganensis subsp. michiganenesis infecting potato in Rusia. Plant Disease, 103(1), doi:10.1094/pdis-04-18-0691-pdn.

Ioannou, N., Psallidas, P.G., Glynos, P. (2000). First record of bacterial canker Clavibacter michiganensis ssp. michiganensis on tomato in Cyprus. Journal of Phytopathology, 148(6), 383-386.

Kleitman Frida, Barash, I., Burger Annette, Iraki, N., Falah, Y., Sessa, G., Weinthal, D., Chalupowicz Laura, Gartemann, K-H., Eichenlaub, R., Manulis-Sasson, S. (2007). Characterization of a Clavibacter michiganensis subsp. michiganensis population in Israel. European Journal of Plant Pathology, 121, 463-475.

Lamichhane, J.R., Balestra, G.M., Varvaro, L. (2011). Severe outbreak of bacterial canker by Clavibacter michiganensis subsp. michiganensis on tomato in central Italy. Plant Disease, 95(2), 221 - Abstract.

Marinescu, G., Costache, M., Stoenescu, A. (1986). Bolile plantelor legumicole [Diseases of vegetable plants] (pp. 555). Ed. Ceres, Bucuresti.

Milijasevic Svetlana, Todorovic, B., Rekanovic, E., Potocnik Ivana, Stepanovic, M., Duduk B. (2009). Geographical distribution of Clavibacter michiganensis subsp. michiganensis in Serbia. IVth Balkan Symposionum on Vegetables and Potatoes, Acta Horticulturae, 830, 585-590.

Myung, I-S., Kim, D.G., An, S.H., Lee, Y-K., Kim, W.G. (2008). First report of bacterial canker of tomato caused by Clavibacter michiganensis subsp. michiganensis in Korea. Plant Disease, 92(10), 1472-1472.

Rădulescu, E., Rafailă, C., Alexandrii, Al., Baicu, T., Olangiu, M., Petrescu, M., Pop, I., Severin, V. (1970). Tratat de fitopatologie agricola [Agricultural Phytopathology Treaty] (Vol III, pp. 44-31). Ed. Academiei Republicii Socialiste România.

Severin, V., Iliescu, C.H. (2006). Bolile bacteriene ale plantelor [Bacterial diseases of plants] (pp. 49, 158-163). Ed. Geea, Bucureşti.

Singh, G., Bharat, N.K. (2017). Studies on bacterial canker (Clavibacter michiganensis subsp. michiganenesis) of tomato (Solanum lycopersicum). International Journal of Current Microbiology and Applied Sciences, 6(9), 317323.

Şahin, F., Uslu, H., Kotan, R., Donmez, M.F. (2002). Bacterial canker, caused by Clavibacter michiganensis ssp. michiganensis, on tomatoes in eastern Anatolia region of Turkey. Plant Pathology, 51, 399.

Valenzuela Miryam, Besoain Ximena, Durand Karine, Cesbron Sophie, Fuentes, S., Claverías Fernanda, Jacques MarieAgnes, Seeger, M. (2018). Clavibacter michiganensis subsp. michiganensis strains from central Chile exhibit low genetic diversity and sequence types match strains in other parts of the world. Plant Pathology, 67(9) doi: $10.1111 /$ ppa.12911.

***Directive 2000/29/ EC on protection measures against the introduction into the community of plant or plant organisms and their liability in the community

(https://eur-lex.europa.eu/legal-content/EN/TXT/PDF/?uri=CELEX:32000L0029\&from=EN).

***EPPO Global databases Clavibacter michiganensis subsp. michiganensis (https://gd.eppo.int/taxon/CORBMI/ distribution).

***Government Decision no. 563/2007 for the approval of the methodological norms for applying the Government of the Ordinance no. 136/2000 regarding the protective measures against the introduction and spread of quarantine organisms for the supply of plants or plant products in Romania (http://madr.ro/docs/fitosanitar/legislatienationala/HG-563-2007-versiune-consolidata_copy.pdf).

***Ghid pentru recunoaşterea şi combaterea bolilor şi dăunătorilor la tomate cultivate în spații protejate (sere, solarii, tuneluri) [Guide for the recognition and control of diseases and pests of tomatoes grown in protected areas (greenhouses, solariums, tunnels)] (https://www.anfdf.ro/sanatate/ghid/ghid_tomate_2019.pdf).

***Program de monitorizare a virusurilor de carantină la tomate şi a bacteriilor de carantină la tomate şi ardei [Monitoring program for quarantine viruses in tomatoes and quarantine bacteria in tomatoes and peppers] (https://www.madr.ro/docs/fitosanitar/programe-monitorizare/pm-virusi-carantina-tomate-ardei-update22.11.2016.pdf). 


\section{Current Trends in Natural Sciences}

Vol. 9, Issue 17, pp. 175-186, 2020

https://doi.org/10.47068/ctns.2020.v9i17.021

Current Trends in Natural Sciences (on-line)

ISSN: 2284-953X

Current Trends in Natural Sciences (CD-Rom)

ISSN: 2284-9521

ISSN-L: 2284-9521

ISSN-L: 2284-9521

***Regulation (EU) 2019/2072 of 28 November 2019 establishing uniform conditions for the implementation of Regulation (EU) 2016/2031 of the European Parliament and the Council, as regards protective measures against pests of plants, and repealing Commission Regulation (EC) No 690/2008 and amending Commission Implementing Regulation (EU) 2018/2019

(https://eur-lex.europa.eu/legal-content/EN/TXT/PDF/?uri=CELEX:32019R2072\&from=EN).

***Scientific Opinion on the pest categorisation of Clavibacter michiganensis subsp. michiganensis (Smith) Davis et al. EFSA Journal 2014, 12(6) (https://efsa.onlinelibrary.wiley.com/doi/epdf/10.2903/j.efsa.2014.3721). 